PAPER • OPEN ACCESS

Sulphate Removal from Wastewater in Constructed Wetland Ecotechnology Using Pumice Amended in the Sand Media

To cite this article: Philiphi de Rozari et al 2020 IOP Conf. Ser.: Mater. Sci. Eng. 833012041

View the article online for updates and enhancements. 


\title{
Sulphate Removal from Wastewater in Constructed Wetland Ecotechnology Using Pumice Amended in the Sand Media
}

\author{
Philiphi de Rozari', Maria Agusta Dua Monang, Denik Sri Krisnayanti ${ }^{2}$ \\ Bibiana Dho Tawa' \\ Department of Chemistry Faculty of Science and Engineering Nusa Cendana \\ University, Kupang, Jalan Adisucipto Penfui Kupang, NTT \\ Department of Civil Engineering Faculty of Science and Engineering Nusa Cendana \\ University, Kupang, Adisucipto Penfui Kupang, NTT \\ Corresponding author: phderozari@yahoo.com or p_derozari@staf.undana.ac.id
}

\begin{abstract}
Sulphate is a part of sulphur compounds which potentially inhibit plant growth and microbial activities in receiving surface water. Thus, it is important to remove concentration of sulphate from wastewater to acceptable concentration before the water is released into aquatic system. Constructed wetlands (CWs) are good option of wastewater treatments due to their lowcost and eco-technology. This research aimed to investigate the removal of sulphate from domestic wastewater using sand media amendment with pumice in CWs. In this experiment, six variations of CWs consisting sand and pumice planted with lemongrass (Cymbopogon citratus) were established. Domestic wastewater was loaded into CWs with loading rate $2 \mathrm{~L} /$ day. Sulphate concentrations were determined in inflows and outflows. The results showed that all treatment significantly remove sulphate concentrations from the inflow. The highest removal efficiency was in the media with $100 \%$ of pumice.
\end{abstract}

\section{Introduction}

As a capital city of East Nusa Tenggara Province (ENTP), Kupang is experiencing problems with the decline in water quality mainly caused by urbanization and population growth. Several rivers in the city of Kupang such as Dendeng and Liliba Rivers have been contaminated by domestic wastewater, which affects the aesthetics of the river such as the colour, smell and taste of water. One of the pollutants caused aesthetic problems in surface water is sulphate. This compound is commonly found in wastewater and natural water body either in surface water or ground water. However, excess of sulphate, in some circumstances, could lead to detrimental effect to human health particularly diarrhoea [1]. In limited oxygen condition, sulphate could produce hydrogen sulphide $\left(\mathrm{H}_{2} \mathrm{~S}\right)$ and organic sulphur that result in environmental problems such as aesthetic issues in water body, water pipe corrosion and plant phytotoxicity [2]. Thus, it is crucial to remove sulphate from domestic wastewater until recommendable concentration before this compound is discharged to water body.

Constructed wetland $(\mathrm{CW})$ is an alternative technology that potentially uses for wastewater treatment. Recently, CWs have been widely used for removing different types of polluted waters because of their low operational and maintain cost, effective pollutant removal and ecotechnology [3-5]. CWs are categorised as free water surface (FWS) and subsurface flow (SSF) regimes [4]. Meanwhile, SSFs 
are further classified into horizontal flow (HF) and vertical flow (VF). The SSFs are widely used for wastewater treatment technology because the treatment processes occur effectively during contact with the media and around the roots and rhizomes of the plants [6]. In addition, SSFs have more capability to reduce odour problems, effectiveness of land area uses, and higher capacity to adsorb pollutant [4].

In SSFs, plants and media play a significant role in removing pollutants. Plants contribute in removing pollutants via production of roots and rhizome for suitable place to microorganisms, filtration processes, plant uptake and absorption processes $[4,7]$. The effectiveness of plants to remove pollutants depends on plant species and plant density [8]. Media, in other hand, plays numerous processes in removing pollutants, particularly through controlling water infiltration, filtering particulate maters, providing surface areas for nutrients which are source of energy for microorganisms and encouraging the growth of microorganisms and plants $[9,10]$.

Removal of pollutants in SSF system occurs through various interactions among media, microorganisms, plants, the atmosphere and the wastewater itself [4]. The pollutant is removed through physical, chemical and biological mechanisms. These mechanisms take place simultaneously. The sulphate removal in SSF system could be via several mechanisms such as precipitation with heavy metals such as $\mathrm{Zn}$ and Fe, microbial oxidation and plant uptake [11-13]. Several authors have investigated the use of media and plants for sulphate removal. Chen et al. [14] have designed five SSF $\mathrm{CW}$ gravel media microcosms, with unplanted control, litter added microcosm, planted (Thypa latifolia) microcosms, and planted plus litter added microcosms to investigate the effect of plants and litters in removal sulphate. The results showed that the presence of Thypa latifolia gave minor contribution in removing sulphate either in the media with additional carbon sources or without additional carbon source. San Miguel-Espinosa et. al. [15] used rice husk as a control media and the same media planted with Thypa angustifolia and Puccinellia frigida to examine the effect of rice husk and plants in removing sulphate. The results showed that control media was more significantly effective in removing sulphate compared to those planted media. The sulphur balance analysis conducted by Hou et al. [16] using constructed wetlands planted with Thypa latifolia revealed that $43-71 \%$ of sulphate removal was found in the gravel and only $8.84-2.34 \%$ was uptaken by the plant. It can be inferred that the presence of Thypa latifolia and Puccinellia frigida in CWs had limited effect on sulphate removal. Regarding the application of CWs in ENTP, it is interesting to explore local media and endemic plants that effectively reduce pollutants from domestic wastewater because of the use of local media in CWs could reduce the investment cost significantly. Thus, it is important to investigate the potential local media and endemic plant in removing sulphate. Lemongrass (Cymbopogon citratus) is classified as perennial grasses and could store higher nutrients from wastewater [17]. The lemongrass also effectively removed suspended solids [18] and has socio-economic purposes particularly for traditional medicine [19]. Since the lemongrass is abundantly available in ENTP, it is crucial to study the effectiveness of CWs planted with lemongrass in removing in removing pollutant. This research aims to investigate the use of pumice amended in sand media planted with lemongrass (Cymbopogon citratus) in CW system for sulphate removal from domestic wastewater.

\section{Material and Methods}

\subsection{Chemicals}

All chemical were analytical grade chemicals. $\mathrm{BaCl}_{2}$ used in this study was obtained from Merck. Solution containing sulphate $100 \mathrm{mg} / \mathrm{L}$ was prepared by adding $1.479 \mathrm{~g}$ of $\mathrm{Na}_{2} \mathrm{SO}_{4}$ (Merck) to a 1000 $\mathrm{mL}$ measuring flask and filling with deionised water to the mark. Buffer solution was prepared by adding $30 \mathrm{~g}$ of $\mathrm{MgCl}_{2} \cdot 6 \mathrm{H}_{2} \mathrm{O}$ (Merck), $5 \mathrm{~g}$ of $\mathrm{CH}_{3} \mathrm{COONa} .3 \mathrm{H}_{2} \mathrm{O}$ (Merck), $1 \mathrm{~g}$ of $\mathrm{KNO}_{3}$ and $20 \mathrm{~mL}$ of $\mathrm{CH}_{3} \mathrm{COOH}$ (99\%) (Merck) to a $1 \mathrm{~L}$ measuring flask containing $500 \mathrm{ml}$ deionised water. The solution was then filled with deionised water to the mark. 
The 2nd International Conference on Chemistry and Material Science (IC2MS)

IOP Publishing

IOP Conf. Series: Materials Science and Engineering 833 (2020) 012041 doi:10.1088/1757-899X/833/1/012041

\subsection{Experimental design and operation}

The experiment was conducted at Department of Chemistry, Nusa Cendana University starting from February - June 2019. Six vertical flow (VF) mesocosms containing media planted with lemongrass (Cymbopogon citratus) and barren media with combination of pumice amended in the sand were constructed (Table 1). The VF mesocosms were created from polyvinyl pipe column with inner diameter and height of $10.2 \mathrm{~cm}$ and $55 \mathrm{~cm}$, respectively. Figure 1 shows the schematic design of VF mesocosm. The media introduced in VF mesocosms consisted of $5 \mathrm{~cm}$ layer of gravel (diameter $10-20 \mathrm{~mm}$ ) placed at the bottom of each VF mesocosms, followed by $40 \mathrm{~cm}$ of layer media in the middle and $5 \mathrm{~cm}$ of gravel at the top. The bottom of VF mesocosms was fitted with the hose and connected to bucket for collecting the outflow. Domestic wastewater was stored in $50 \mathrm{~L}$ containers and fed six VF mesocosms. The VF mesocosms were loaded daily with domestic wastewater with hydraulic loading rate of 2 L/day. The media used in this research were pure sand, pure pumice and combination among them with and without planted with lemongrass (Table 1).

Table 1. Media composition in VF mesocosms.

\begin{tabular}{|c|c|c|c|c|}
\hline \multirow{2}{*}{ No. } & \multirow{2}{*}{ Media treatment } & \multicolumn{2}{|c|}{$\%$ Media } & \multirow{2}{*}{ Plant } \\
\hline & & Sand & Pumice & \\
\hline 1 & CW1 & $100 \%$ & $0 \%$ & - \\
\hline 2 & CW2 & $90 \%$ & $10 \%$ & - \\
\hline 3 & CW3 & $50 \%$ & $50 \%$ & - \\
\hline 4 & CW4 & $0 \%$ & $100 \%$ & - \\
\hline 5 & CW5 & $90 \%$ & $10 \%$ & + \\
\hline 6 & CW6 & $50 \%$ & $50 \%$ & + \\
\hline
\end{tabular}

$+=$ planted with lemongrass (Cymbopogon citratus)

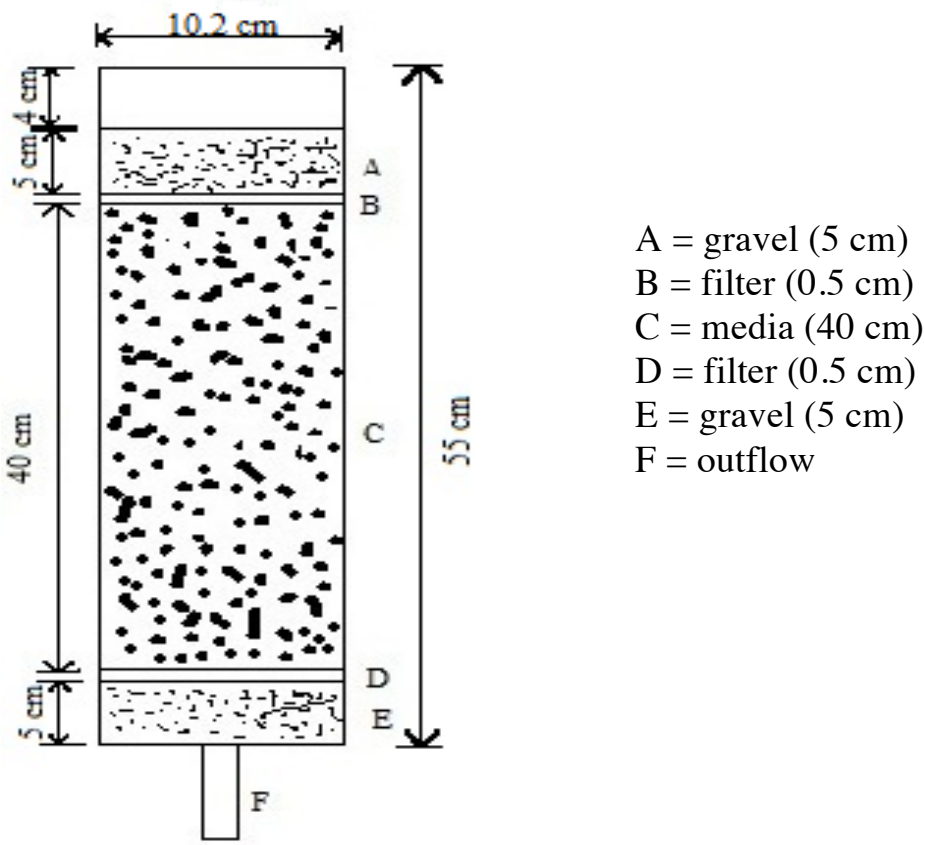

Figure 1. Schematic of VF mesocosm.

\subsection{Media characterisation}

The sand was sampled from Takari in Kupang Disctrict and the pumice was obtained from Tuamese Village, Biboki Anleu Subdistrict, The District of North Centre Timor (Timor Tengah Utara). 
Characterization of sand and pumice were carried out before these materials are applied as media in CW systems. The parameters characterized were included cation exchange capacity, organic matter, $\mathrm{pH}$, FTIR and XRF. CEC was determined using silver thiourea methods [20]. The analysis of pH is based on Methods of Analysis for Soils of Arid and Semi-Arid Regions [21]. Soil organic matter was analysed using gravimetric methods according to ASTM D 2974.

\subsection{Water sample and collection}

The inflows and outflows were collected every week for the first five weeks starting from February to April 2019. The collection of the samples was then carried out every two weeks from April to June 2019. Sulphate concentration was measured in each sampling event. Sulphate samples were analysed using turbidimetry based on the national Indonesian standard methods SNI 06-6989.20-2004, meanwhile $\mathrm{pH}$ was measured using $\mathrm{pH}$ meter based on the standard methods for the examination of water and wastewater [19].

\subsection{Data analysis}

SPSS 21 software was applied to analyse the data obtained from the experiment. Sulphate concentrations from inflows and outflows were determined by the mean and standard deviations. Then, the performance of various types of media either planted or unplanted with lemongrass in removing sulphate was calculated using the percentage removal efficiency (equation 1), where $\mathrm{C}_{i}$ and $\mathrm{C}_{f}$ were inflow and outflow concentrations, respectively.

$$
(\% \mathrm{R})=\frac{C_{i n-} C_{e f}}{C_{\text {in }}} \times 100 \%
$$

The significant difference of the media treatment was statistically analysed using One-way ANOVA. Tukey HSD post-hoc tests were then conducted to deeply address the significant difference of each treatment. In all cases, a significant level of $\alpha=0.05$ was used.

\section{Result and discussion}

In this study, sulphate in domestic wastewater was treated using VF mesocosms containing six different types of media with combination of sand and pumice (Table 1). In this study, the media was firstly characterized and the inflow and outflow concentrations of sulphate in the six different types of media were determined.

\subsection{Media Characterisation}

As shown in Table 2, pumice had a higher organic matter than sand while water content of sand and pumice determined by gravimetric methods was almost the same which was 1.6 and $1.1 \%$, respectively. The $\mathrm{pH}$ of sand and pumice were 8.05 and 8.17 , respectively. This indicated that these media slightly in the base environment. The results of CEC measurement revealed that pumice had the higher CEC compared to sand. The CEC in the media is influenced by soil $\mathrm{pH}$, organic matter, and type of clay. In this research, the higher CEC in the pumice compared to sand media could be influenced by the presence of organic matter. The results of mineral content using XRF (Figure 2) showed that the main elements of pumice were $\mathrm{SiO}_{2}, \mathrm{Fe}_{2} \mathrm{O}_{3}, \mathrm{CaO}, \mathrm{Al}_{2} \mathrm{O}_{3}$, and $\mathrm{K}_{2} \mathrm{O}$ with percentage of 49.0, 16.2, 11.9, 11.0, and 8.4\%, respectively. For sand media, the main elements were $\mathrm{CaO}(41.9 \%), \mathrm{SiO}_{2}(38.0 \%), \mathrm{Fe}_{2} \mathrm{O}_{3}(14.9 \%)$, and $\mathrm{TiO}_{2}(1.5 \%)$. 
The 2nd International Conference on Chemistry and Material Science (IC2MS) IOP Publishing IOP Conf. Series: Materials Science and Engineering 833 (2020) 012041 doi:10.1088/1757-899X/833/1/012041

Table 2. Characterization of sand and pumice.

\begin{tabular}{ccc}
\hline \multirow{2}{*}{ Parameters } & \multicolumn{2}{c}{ Media } \\
\cline { 2 - 3 } & Sand & Pumice \\
\hline Organic matter $(\%)$ & 3.1 & 10.9 \\
$\mathrm{H}_{2} \mathrm{O}(\%)$ & 1.6 & 1.1 \\
$\mathrm{pH}$ & 8.05 & 8.17 \\
$\mathrm{CEC}(\mathrm{cmol}(+) / \mathrm{kg})$ & 47.76 & 50.88 \\
\hline
\end{tabular}
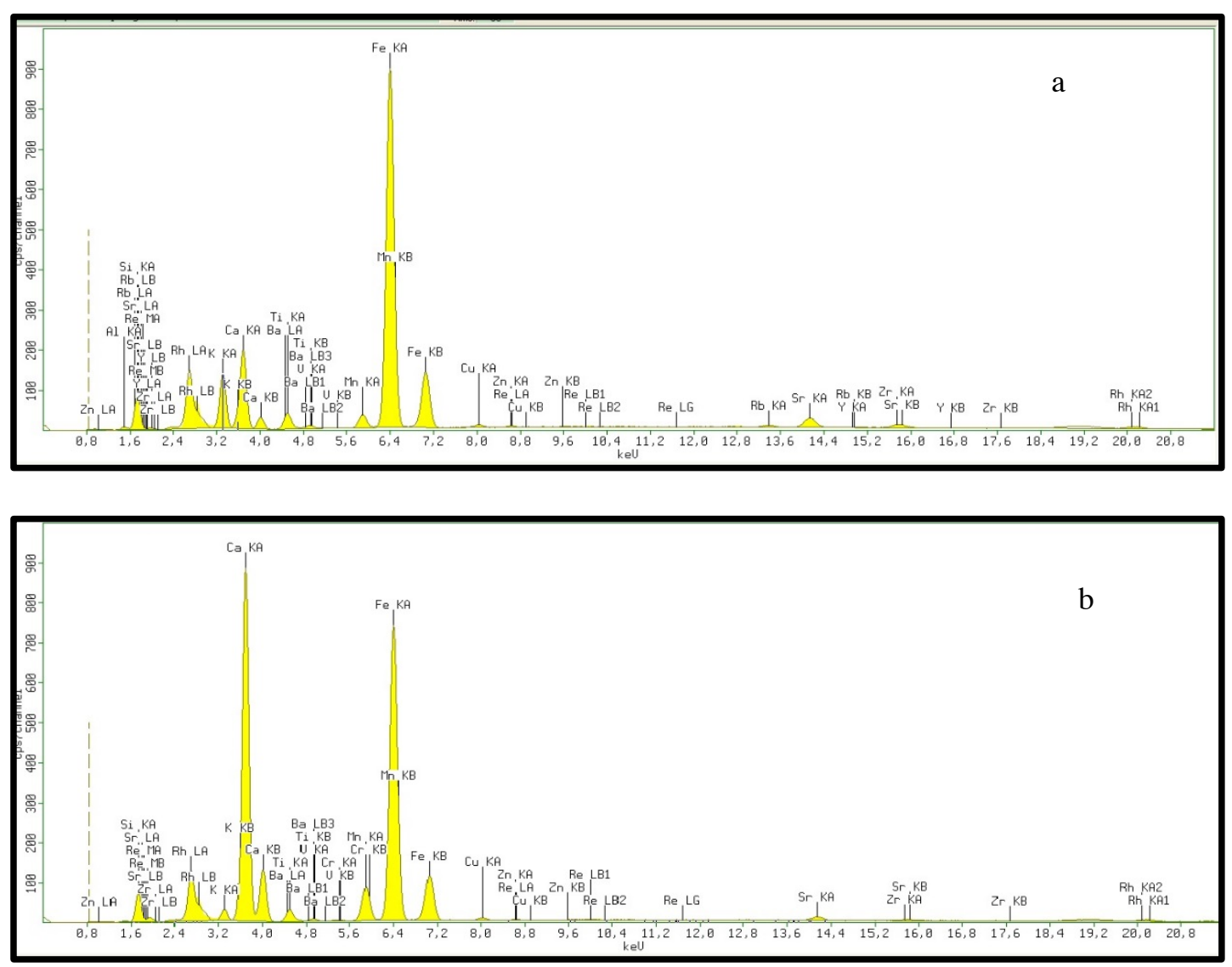

Figure 2. XRF spectra of (a) pumice and (b) sand.

The results of FTIR spectra for pumice and sand are shown in Figure 3. As shown in Figure 3a, FTIR spectra for sand media sample contained several peaks. The band at $1035 \mathrm{~cm}^{-1}$ and $1166 \mathrm{~cm}^{-1}$ were assigned to Si-O-Si stretching. The presence of $\mathrm{Si}-\mathrm{O}$ was supported by the peaks at $518 \mathrm{~cm}^{-1}$ and $462 \mathrm{~cm}$ '. This indicated that siloxane and silicon compounds could be available in sand media sample. This spectrum also showed the presence of $\mathrm{H}_{2} \mathrm{O}$ represented by $\mathrm{O}-\mathrm{H}$ stretching at $3400 \mathrm{~cm}^{-}$. Several peaks were appeared in the pumice spectra (Figure $3 \mathrm{~b}$ ). The peak at $1031.95 \mathrm{~cm}^{-1}$ was attributed to Si-O-Si stretching. The $\mathrm{O}-\mathrm{H}$ stretching was identified at $3458.48 \mathrm{~cm}^{-1}$ indicating that the pumice contained $\mathrm{H}_{2} \mathrm{O}$. The bands at $459 \mathrm{~cm}^{-}$and $435 \mathrm{~cm}^{-1}$ were assigned to Si-O-Al and Si-O-Si asymmetry bend, respectively. It could be concluded that the pumice contained siloxane and silicon compounds [23]. 


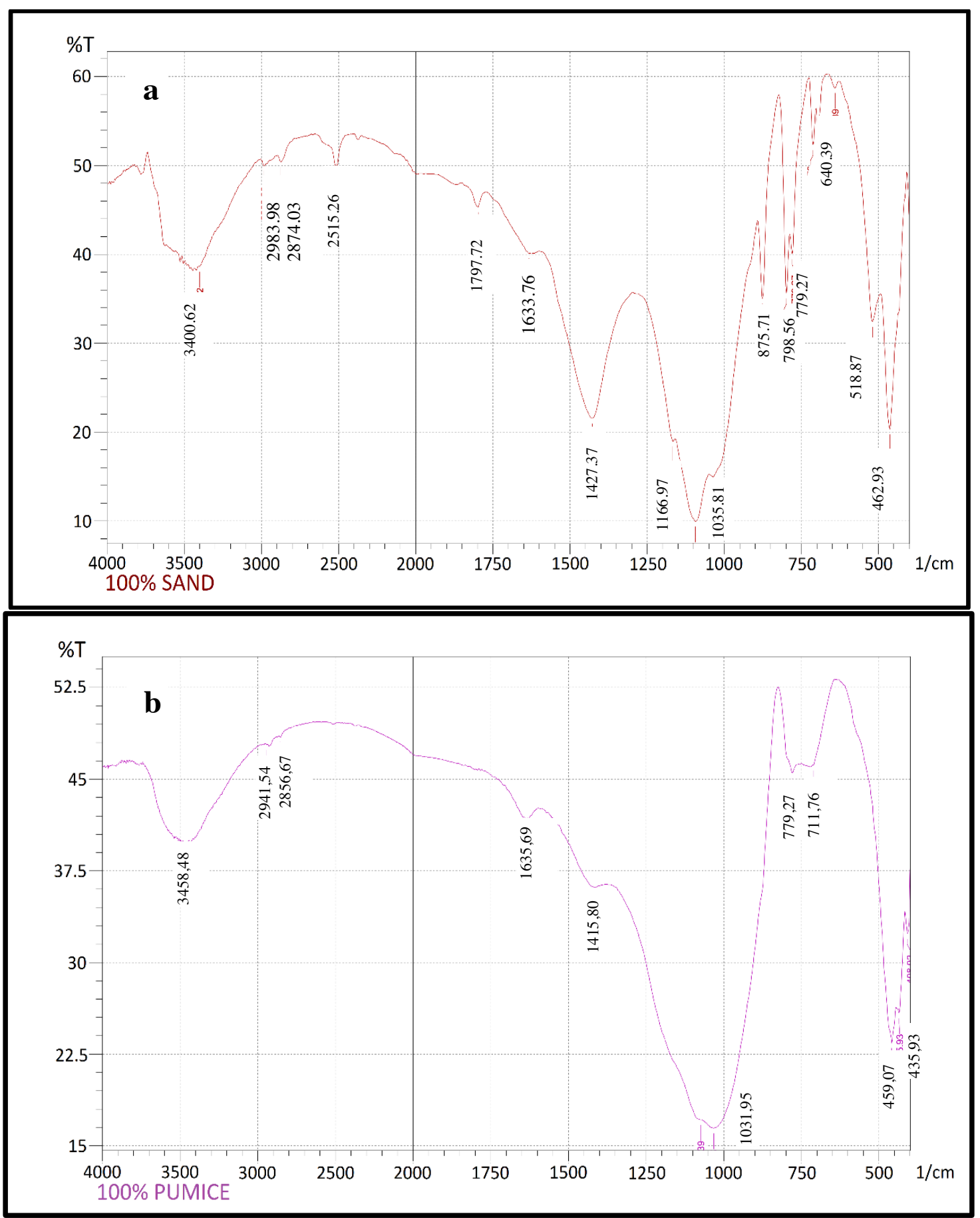

Figure 3. FTIR Spectra of (a) pumice and (b) sand.

\subsection{Sulphate removal}

Figure 4 shows the inflows and outflows of sulphate concentrations in the VF mesocosms with six media treatments loaded with domestic wastewater. Inflow concentrations were fluctuated ranging from 17 $\mathrm{mg} / \mathrm{L}$ to $31 \mathrm{mg} / \mathrm{L}$ meanwhile sulphate concentrations in the outflow ranged from $1.5 \mathrm{mg}-14.7 \mathrm{mg} / \mathrm{L}$ (Figure 4). The highest outflow concentration of sulphate was observed in media containing $50 \%$ sand and pumice (CW3) while the lowest outflow concentration was observed in the media with $100 \%$ pumice (CW4). This indicated that the highest removal efficiency was obtained in the $100 \%$ pumice 
The 2nd International Conference on Chemistry and Material Science (IC2MS)

IOP Publishing

IOP Conf. Series: Materials Science and Engineering 833 (2020) 012041 doi:10.1088/1757-899X/833/1/012041

media (CW4), while the media containing 50\% sand and pumice (CW3) was the poorest performance. One-way ANOVA analysis showed that significant differences were observed between inflow and outflow concentrations indicating that the six various VF mesocosms had a better performance in reducing pollutants. However, there were no significant differences in sulphate concentrations among six VF mesocosms. This suggested that either addition of pumice in sand media or the presence of plants in VF mesocosms did not significantly influence the performance of VF mesocosms in removing sulphate. This result was in line with the result obtained by [2] which revealed that the presence of plants only had a minor effect for sulphate removal.

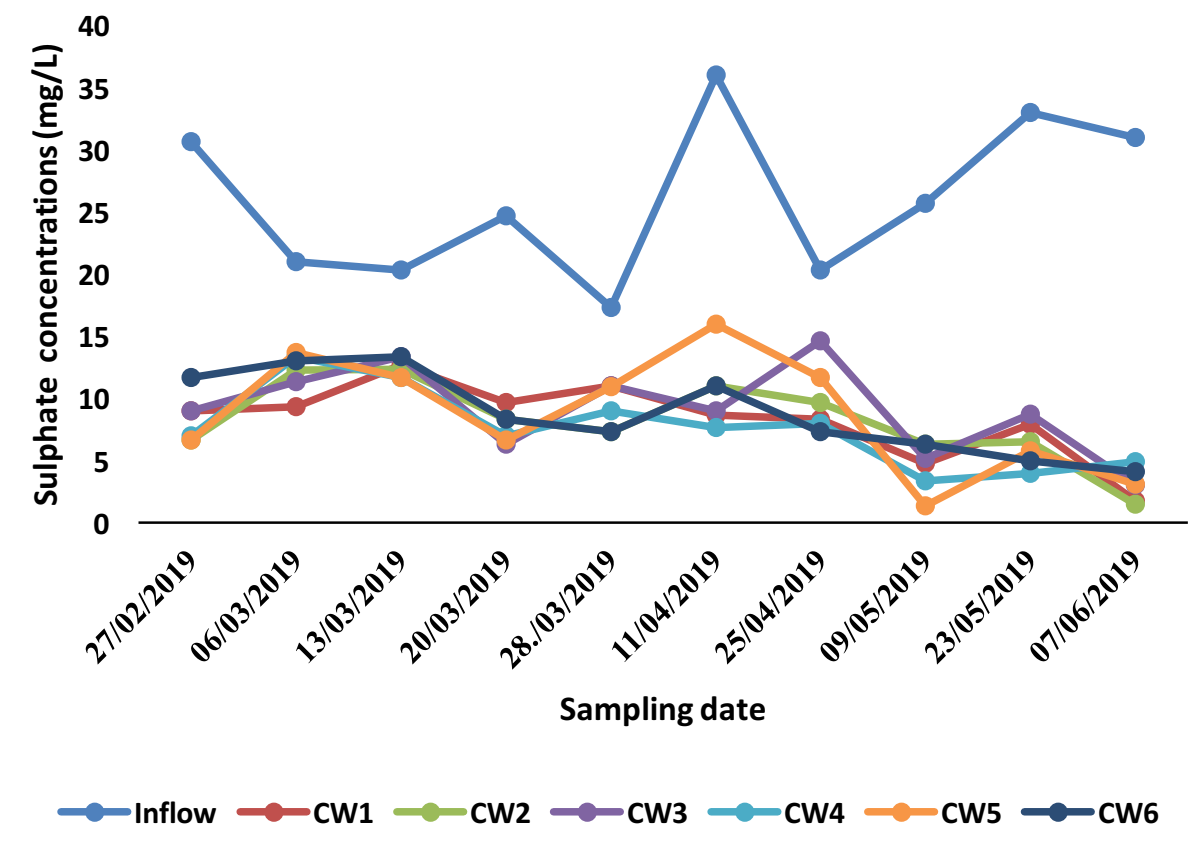

Figure 4. Sulphate concentrations $(\mathrm{mg} / \mathrm{L})$ in different types VF mesocosms loaded with domestic wastewater (the values shown in the figure are in average).

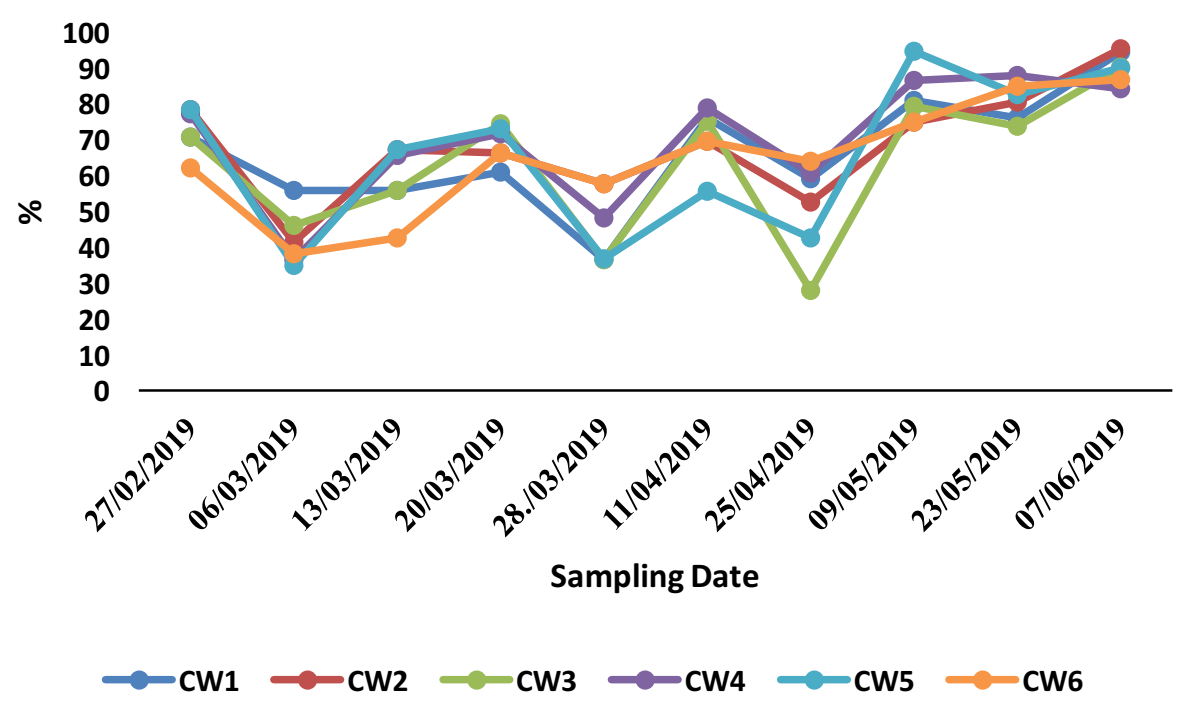

Figure 5. Percentage of sulphate removal (\%) from domestic wastewater. 
It was revealed that the removal efficiency of sulphate in six VF mesocosms were in the range of 62 - $69 \%$ (Figure 5). Several possible mechanisms for sulphate removal in CW systems included plant uptake, hydrogen sulphide emission due to the presence of bacterial sulphate reduction, precipitation and adsorption of sulphur compound in media due to the presence of calcium and iron [14, 24,25]. Since VF mesocosms had aerobic condition, emission of hydrogen sulphide might not significantly contribute in removing sulphate. The main possible mechanisms occurring in sulphate removing could be the adsorption and precipitation which occurred simultaneously because all the media was in the higher $\mathrm{pH}$ value (approximately around 8) and contained high proportion of $\mathrm{Fe}$ and $\mathrm{Ca}$. The precipitation mechanisms, particularly due to the availability of Fe, might not provide significant contribution because of higher $\mathrm{pH}$ value. In addition, competition with other compounds could affected the removal efficiency of sulphate. Since all the media contained silicon compound and the inflows were obtained from domestic wastewater, competition among sulphate and other elements and compound cannot be avoided. This condition could reduce the removal efficiency of all media in removing sulphate.

\section{Conclusion}

This study revealed successful performance of pumice amended in sand media planted with Cymbopogon citratus in removing sulphate ions from aqueous solution. All six media significantly removed sulphate concentrations with the removal efficiency of $62-69 \%$. However, no significant differences were observed among these VF mesocosms. This suggested that addition of pumice in sand media and the presence of plants in VF mesocosms did not significantly affected VF mesocosms for sulphate removal. The main contribution mechanisms for sulphate removal could be the adsorption mechanism. Therefore, further investigation is needed to understand the mechanism of sulphate removal.

\section{Acknowledge}

This research is financially supported by Directorate of Research and Community Service of the Directorate General of Strengthening Research and Development at the Ministry of Research, Technology and Higher Education (Grant No 47/UN15.19/PL/2019). The authors would like to acknowledge Ministry of Research, Technology and Higher Education for funding this research project.

\section{References}

[1] López P, Pérez-Rodríguez I, Estrany F, Devesa R 2017 J Water Supply: Res T. 66(8) 598-605.

[2] Chen Y, Wen Y, Zhou Q, Huang J, Vymazal J, Kuschk P 2016 Water Res. 102 572-81.

[3] Abou-Elela SI, Golinelli G, El-Tabl AS, Hellal MS Water Sci Technol. 69(1) 38-47.

[4] Kadlec RH, Wallace S 2008 Treatment Wetlands. CRC press

[5] Garcia J, Rousseau DP, Morato J, Lesage E, Matamoros V, Bayona JM 2010 Crit Rev Env Sci Tec. 40(7) 561-661.

[6] Shutes RBE 2001 Environ Int. 26 (5-6) 441-7.

[7] Sandoval L, Zamora-Castro SA, Vidal-Álvarez M, Marín-Muñiz JL 2019 Applied Sciences. 9(4) 685.

[8] Saeed T, Sun G. A 2012 J. Environ Manage. 112 429-48.

[9] Gorgoglione A, Torretta V 2018 Sustainability. 10(11) 3910.

[10] Valipour A, Ahn Y-H 2016 Environ Sci Pollut Res. 23(1) 180-97.

[11] Wu S, Chen Z, Braeckevelt M, Seeger EM, Dong R, Kästner M 2012 Water Res. 46(6) 1923-32.

[12] Wu S, Jeschke C, Dong R, Paschke H, Kuschk P, Knöller K 2011 Water Res. 45(20) 6688-98.

[13] Faulwetter JL, Gagnon V, Sundberg C, Chazarenc F, Burr MD, Brisson J 2009 Ecol Eng. 35(6) 987-1004.

[14] Chen Y, Wen Y, Zhou J, Tang Z, Li L, Zhou Q 2014 Water Res. 59 1-10.

[15] San Miguel-Espinosa C, Rámila C, Leiva E, Lizama-Allende K 2019 Bioresources. 14(1) 363-75.

[16] Hou J, Guo W, Wen Y, editors. 2018 IOP Conference Series: Earth and Environmental Science. 
The 2nd International Conference on Chemistry and Material Science (IC2MS) IOP Publishing

IOP Conf. Series: Materials Science and Engineering 833 (2020) 012041 doi:10.1088/1757-899X/833/1/012041

[17] Rao E. P. 2013.:Plant Sciences Reviews 2012. 105IOP Publishing.

[18] Wanyama J, Herremans K, Maetens W, Isabirye M, Kahimba F, Kimaro D, Poesen J, Deckers J 2012 Soil Use and Manage. 28 409-418.

[19] Ekpenyong C E, Akpan E, Nyoh, A. 2015 Chin J of Nat Medicines. 13 321-337.

[20] Pleysier J, Juo A 1980 Soil Sci. 1980;129(4):205-11.

[21] Bashour II, Sayegh AH 2007 Methods of analysis for soils of arid and semi-arid regions. Rome: FAO; 2007.

[22] APHA 2005 Standard methods for the examination of water and wastewater. 21 ed. Washington DC, USA:

[23] Anbalagan G, Prabakaran A, Gunasekaran S 2010 J. Appl Spectrosc. 77(1) 86-94.

[24] Baldwin DS, Mitchell A 2012 Water res. 46(4) 965-74.

[25] Rickard D, Morse JW 2005 Mar chem. 97(3-4) 141-97. 